\title{
QUANTIFICATION OF LEYDIG CELLS AND MEASUREMENT OF LEYDIG-CELL SIZE FOLLOWING ADMINISTRATION OF HUMAN CHORIONIC GONADOTROPHIN TO NORMAL MEN
}

\author{
C. G. HELLER AND D. R. LEACH \\ Pacific Northwest Research Foundation, 1102 Columbia Street, \\ Seattle, Washington 98104, U.S.A.
}

(Received 18th Fune 1970)

\begin{abstract}
Summary. Six normal men were injected with 4000 i.u. of HGG intramuscularly three times a week for 6 weeks or every 2 nd day for 16 weeks. Levels of urinary testosterone and oestrogens were measured. Leydig cells were quantified on the basis of the Leydig cell/Sertoli cell ratio, and Leydig-cell size was measured.

Following both 6 and 16 weeks HCG administration, four subjects showed no change in Leydig-cell numbers. The remaining subjects showed slight increases or decreases. Levels of urinary testosterone and oestrogen increased. It is concluded that there is no consistent increase in Leydig-cell numbers following HCG administration. Measurements of Leydig-cell nucleus and cytoplasm revealed a significant increase in the size of both at 6 and 16 weeks in all but one subject. It is concluded that the increased activity of the Leydig cells is related to their increase in size and not to an increase in number as had been reported.
\end{abstract}

\section{INTRODUCTION}

The Leydig cells of the normal adult human male are stimulated by interstitialcell-stimulating hormone (ICSH) to produce androgens and oestrogens. Their normal function may be altered by the administration of certain drugs and hormones. Among these are testosterone which depresses their activity and human chorionic gonadotrophin (HCG) which stimulates their activity.

Stimulation of Leydig cells by HCG is reflected by increased production of 17-ketosteroids (Maddock \& Nelson, 1952; Maddock, Epstein \& Nelson, 1952; Leach, Maddock, Tokuyama, Paulsen \& Nelson, 1956; Tamm, Apostolakis \& Voight, 1965), oestrogen (Maddock \& Nelson, 1952; Maddock et al., 1952; Leach et al., 1956; Tamm et al., 1965) and testosterone (Tamm et al., 1965; Cleveland, Ahmad, Sandberg \& Savard, 1966). It was thought this increase could be correlated with cytological observations. Indeed, Maddock \& Nelson (1952) reported that the increase in the activity of the Leydig cells was correlated with an increase in their numbers. However, Maddock \& Nelson (1952) 
based their correlation upon a subjective impression from the testicular biopsies, making no actual measurements. The present experiment was designed to determine if the increase in Leydig-cell activity after administration of HCG was due to an increase in their number and/or size.

\section{MATERIALS AND METHODS}

Six normal men, ranging in age from 25 to 34 years, volunteered as subjects for repeated testicular biopsies. The normality of their reproductive system was confirmed on the basis of physical examination, sperm count (twenty weekly collections per subject), urinary testosterone and germinal cell cytology. These men were divided into two groups which received intramuscular injections of 4000 i.u. HCG either three times a week for 6 weeks (Subjects 189, 218 and 232) or every 2 nd day for 16 weeks (Subjects 44, 251 and 253). Biopsies were obtained during the control period and at 6 or 16 weeks of HCG administration. Subject 44 supplied biopsy material at 6 and 16 weeks.

Biopsies were obtained and processed by the method of Rowley \& Heller (1966). At the time of each biopsy, one piece was fixed in Cleland's solution to produce good nuclear detail. A second piece was fixed in Zenker-formol solution to delineate the cytoplasmic limits of the cells. Serial sections (150 to 200) were cut at a thickness of $4 \mu \mathrm{m}$. Cleland-fixed sections were stained with iron haematoxylin and eosin, while Zenker-fixed sections were stained with Harris haematoxylin and eosin.

The Gleland-fixed biopsies were used to quantify the number of Leydig cells before and after HCG administration, using the Leydig cell/Sertoli cell (LC/SC) ratio method (Heller, Lalli, Pearson \& Leach, 1971). Comparisons were always made on biopsies obtained from the same testis since the LC/SC ratios of the two testes may vary in the same man (Heller et al., 1971). To determine statistical significance, control and administration biopsies were compared using the Student's $t$ test. All changes were determined to be significant at the $P \leqslant 0.05$ level.

The Zenker-formol-fixed biopsies were used to measure the size of the individual Leydig cells and their nuclei. At least forty Leydig cells from each biopsy were measured at $\times 1000$ with a Filar ocular micrometer. Because the Leydig-cell nucleus was at times oval and the whole cell polyhedral in shape, the longest dimension of the nucleus and of the whole cell was estimated to establish consistent measuring criteria.

The diameters of cross sections of the seminiferous tubules were measured to assess the amount of shrinkage caused by HCG administration. The number of Sertoli cells in each measured tubule was recorded to give an indication of the shrinkage in the length of the tubule.

Both control values and several values per month were obtained for urinary testosterone during HCG administration. Five consecutive 12-hr (overnight) urine samples were collected at monthly intervals during control, HCG administration and postadministration periods. In addition, daily samples were collected on some subjects. Estimations of urinary testosterone and oestrogen were performed on aliquots of the 5-day samples and of urinary testosterone 
only on specified daily samples. The daily results were combined to arrive at the monthly totals reported in the results. The number of daily observations is noted in the tables. Urine collections were stored below $5^{\circ} \mathrm{C}$ until the extraction procedures were performed. After adding labelled testosterone, the method utilized involved hydrolysis of the testosterone glucuronide in the urine, solvent extraction and washing to remove polar contaminants. Thin-layer and paper chromatography further purified the sample. The testosterone-containing zones on the chromatograms were located with a radiochromatogram scanner. The testosterone fraction was quantified using gas-liquid chromatography by comparing the detector response of the sample testosterone to that of standard testosterone. The results are reported as $\mu \mathrm{g} / 24 \mathrm{hr}$ and represent testosterone and epitestosterone since the two were not measured separately.

Urinary oestrogenic activity was determined by bioassay using the uterine weight of the rat as an endpoint (Lauson, Heller, Golden \& Sevringhaus, 1939). Results were reported as $\mu \mathrm{g}$ of oestradiol benzoate $/ 24 \mathrm{hr}$.

\section{RESULTS}

The effect of HCG on the numbers of Leydig cells

The results of the assessment of Leydig-cell numbers after 6 or 16 weeks of administration are shown in Table 1. Following 6 weeks of HCG administration, two subjects (189 and 44) showed no significant change in Leydig-cell numbers.

TABLE 1

RESULTS OF QUANTIFICATION OF LEYDIG GELLS FOLLOWING HCG ADMINISTRATION

\begin{tabular}{|c|c|c|c|}
\hline $\begin{array}{c}\text { Subject } \\
\text { no. }\end{array}$ & $\begin{array}{l}\text { Control } \\
\text { Leydig cell/Sertoli cell } \\
\text { ratio } \pm S . E .\end{array}$ & $\begin{array}{l}\text { Administration of HCG } \\
\text { for } 6 \text { weeks } \\
\text { Leydig cell/Sertoli cell } \\
\text { ratio } \pm S . E .\end{array}$ & $\mathbf{P}^{*}$ \\
\hline 189 & $3843 / 6769=0.56 \pm 0.02$ & $3724 / 6496=0.57 \pm 0.02$ & N.S. \\
\hline 218 & $1056 / 3956=0.27 \pm 0.01$ & $1048 / 4916=0.21 \pm 0.02$ & Decrease $P=0.005$ \\
\hline 232 & $3173 / 8507=0.37 \pm 0.01$ & $3082 / 7120=0.43 \pm 0.01$ & Increase $P=0.005$ \\
\hline 44 & $3076 / 4614=0 \cdot 67 \pm 0 \cdot 03$ & $\begin{array}{c}4162 / 5858=0.71 \pm 0.02 \\
16 \text { Weeks } H C G\end{array}$ & N.S. \\
\hline 44 & $3076 / 4614=0.67 \pm 0.03$ & $4497 / 7655=0.59 \pm 0.02$ & Decrease $P=0.025$ \\
\hline $\begin{array}{l}251 \\
253\end{array}$ & $5067 / 7037=0.72 \pm 0.04$ & $2176 / 2826=0.77 \pm 0.04$ & N.S. \\
\hline $\begin{array}{l}\text { Right testis } \\
\text { Left testis }\end{array}$ & $\begin{array}{l}3059 / 7177=0.43 \pm 0.02 \\
4169 / 8683=0.48 \pm 0.03\end{array}$ & $\begin{array}{l}1858 / 3775=0.49 \pm 0.01 \\
1782 / 3446=0.52 \pm 0.02\end{array}$ & $\begin{array}{l}\text { Increase } P=0.05 \\
\text { N.S. }\end{array}$ \\
\hline
\end{tabular}

N.S., Not significant.

* For this report, $P \leqslant 0.05$ is the criterion for statistical significance.

Subject 218 showed a decrease and Subject 232 showed an increase. After 16 weeks of HCG administration, Subject 251 showed no significant change, as did the left testis of Subject 253. Subject 44 showed a decrease and the right testis of Subject 253 showed an increase.

The results from the quantitative analysis gave rise to the conclusion that 
there is no consistent change in Leydig cell numbers following 6 or 16 weeks of HGG administration.

\section{Effect of HCG on the size of Leydig cells}

The results of measuring the size of Leydig cells are shown in Table 2 . All but one biopsy (Subject 251) showed a significant increase in the size of the nucleus and the size of the cytoplasm of the Leydig cells. From these data, it is concluded that Leydig cell size increased with the administration of HCG.

TABLE 2

LEYDIG-CELL MEASUREMENTS (IN $\mu \mathrm{m}$ )

\begin{tabular}{|c|c|c|c|c|c|}
\hline $\begin{array}{l}\text { Subject } \\
\text { no. }\end{array}$ & Biopsy & $\begin{array}{c}\text { Cytoplasm } \\
\text { mean } \pm S . E .\end{array}$ & $\mathrm{P}^{*}$ & $\begin{array}{c}\text { Nucleus } \\
\text { mean } \pm S . E .\end{array}$ & $\mathbf{P}^{*}$ \\
\hline 189 & $\begin{array}{l}\text { Control } \\
6 \text { weeks HCG }\end{array}$ & $\begin{array}{l}12 \cdot 0 \pm 0.3 \\
12.9 \pm 0.4\end{array}$ & Increase $P=0.025$ & $\begin{array}{l}5 \cdot 3 \pm 0 \cdot 04 \\
5 \cdot 8 \pm 0 \cdot 07\end{array}$ & Increase $P=0.0005$ \\
\hline 218 & $\begin{array}{l}\text { Control } \\
6 \text { weeks HCG }\end{array}$ & $\begin{array}{l}15 \cdot 9 \pm 0 \cdot 4 \\
17 \cdot 4 \pm 0 \cdot 6\end{array}$ & Increase $P=0.025$ & $\begin{array}{l}6 \cdot 3 \pm 0 \cdot 06 \\
6 \cdot 7 \pm 0.08\end{array}$ & Increase $P=0.0005$ \\
\hline 44 & $\begin{array}{l}\text { Control } \\
6 \text { weeks HCG } \\
16 \text { weeks HCG }\end{array}$ & $\begin{array}{l}13.4 \pm 0.6 \\
14.6 \pm 0.7 \\
14.9 \pm 0.4\end{array}$ & $\begin{array}{l}\text { Increase } P=0.05 \\
\text { Increase } P=0.01\end{array}$ & $\begin{array}{l}5.6 \pm 0.09 \\
5.9 \pm 0.06 \\
6 \cdot 2 \pm 0.09\end{array}$ & $\begin{array}{l}\text { Increase } P=0 \cdot 005 \\
\text { Increase } P=0 \cdot 0005\end{array}$ \\
\hline 251 & $\begin{array}{l}\text { Control } \\
\text { I6 weeks HCG }\end{array}$ & $\begin{array}{l}13 \cdot 2 \pm 0.7 \\
13.5 \pm 0.3\end{array}$ & N.S. & $\begin{array}{l}5 \cdot 8 \pm 0.09 \\
6 \cdot 1 \pm 0.08\end{array}$ & N.S. \\
\hline $\begin{array}{l}253 \\
\text { Right testis }\end{array}$ & $\begin{array}{l}\text { Control } \\
16 \text { weeks HCG }\end{array}$ & $\begin{array}{l}13 \cdot 5 \pm 0.3 \\
13 \cdot 2 \pm 0.4\end{array}$ & Decrease $P=0.025$ & $\begin{array}{l}6 \cdot 1 \pm 0.06 \\
5 \cdot 7 \pm 0.08\end{array}$ & Decrease $P=0.0005$ \\
\hline Left testis & $\begin{array}{l}\text { Control } \\
16 \text { weeks HCG }\end{array}$ & $\begin{array}{l}12 \cdot 3 \pm 0 \cdot 03 \\
13 \cdot 3 \pm 0 \cdot 3\end{array}$ & Increase $P=0.01$ & $\begin{array}{l}5.6 \pm 0.06 \\
5.8 \pm 0.05\end{array}$ & Increase $P=0.0005$ \\
\hline
\end{tabular}

N.S., Not significant.

* For this report $P \leqslant 0.05$ is the criterion for statistical significance.

\section{Effect of HCG on testicular architecture}

Measuring tubular cross sections revealed shrinkage in diameter of the seminiferous tubules in all but one biopsy at both 6 and 16 weeks (Table 3). Shrinkage in tubular length, revealed by an increase in the average number of Sertoli cells per tubular cross section, was not significant in any biopsies at 6 weeks, but was significant in all biopsies obtained at 16 weeks.

\section{Effect of HCG on urinary testosterone production}

Following administration of HCG, 4000 i.u. three times a week, there was a marked rise in testosterone in two of three subjects and a transient rise in the third. The increase in Subject 218 was not statistically significant because of the wide variation in the two values during administration. Following HCG administration at this dose, testosterone values promptly return to control levels (Table 4).

Administration of 4000 i.u. HCG every 2 nd day was associated with a pronounced rise in testosterone observed in each of three subjects. After discontinuing HCG administration, testosterone levels took a longer period of time to return to control levels (Table 5). 


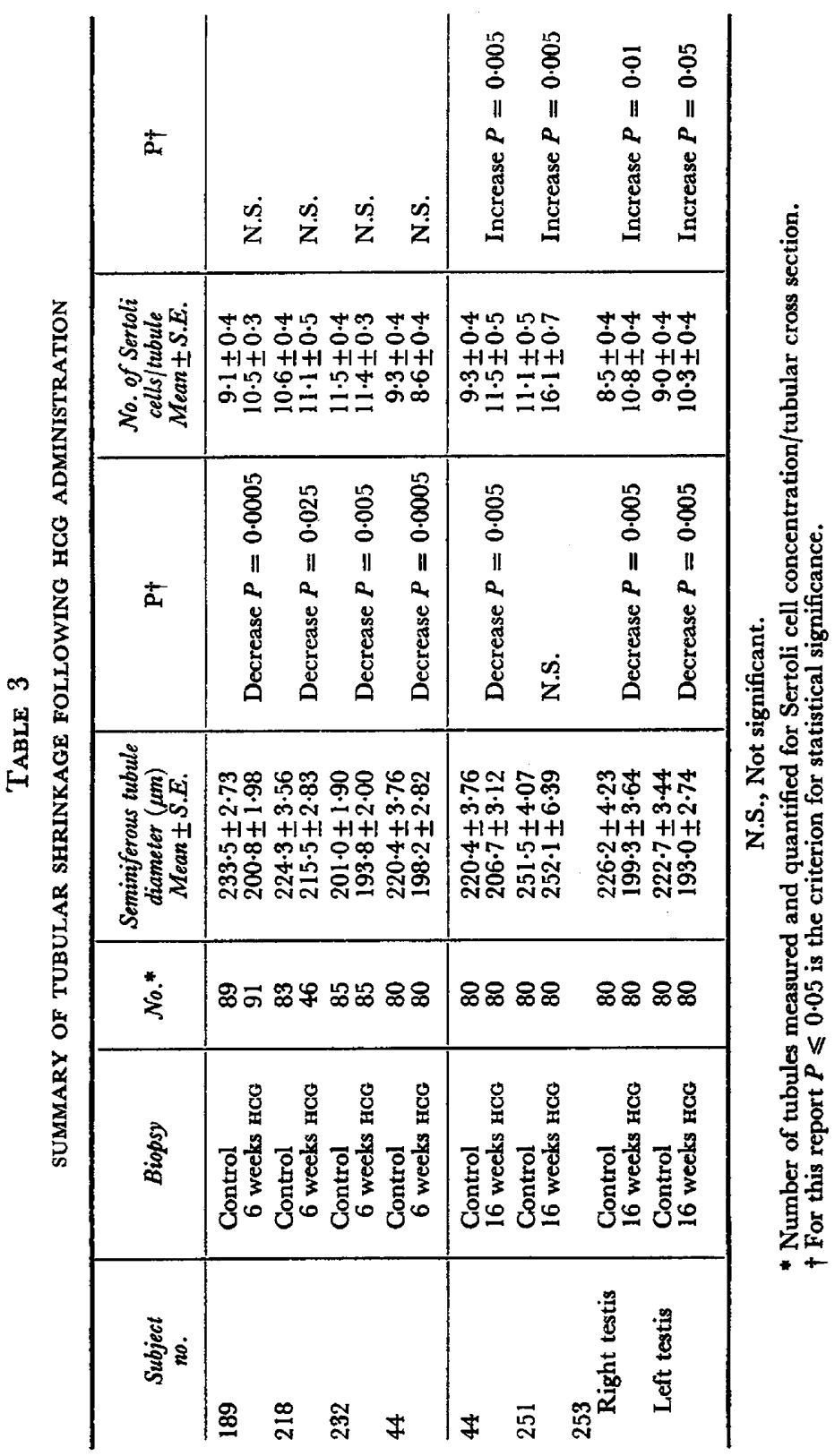


TABLE 4

CONTROL, ADMINISTRATION AND POSTADMINISTRATION MONTHLY TESTOSTERONE* AND OESTROGEN $\dagger$ VALUES ( 6 WEEKS HGG ADMINISTRATION THREE TIMES A WEEK)

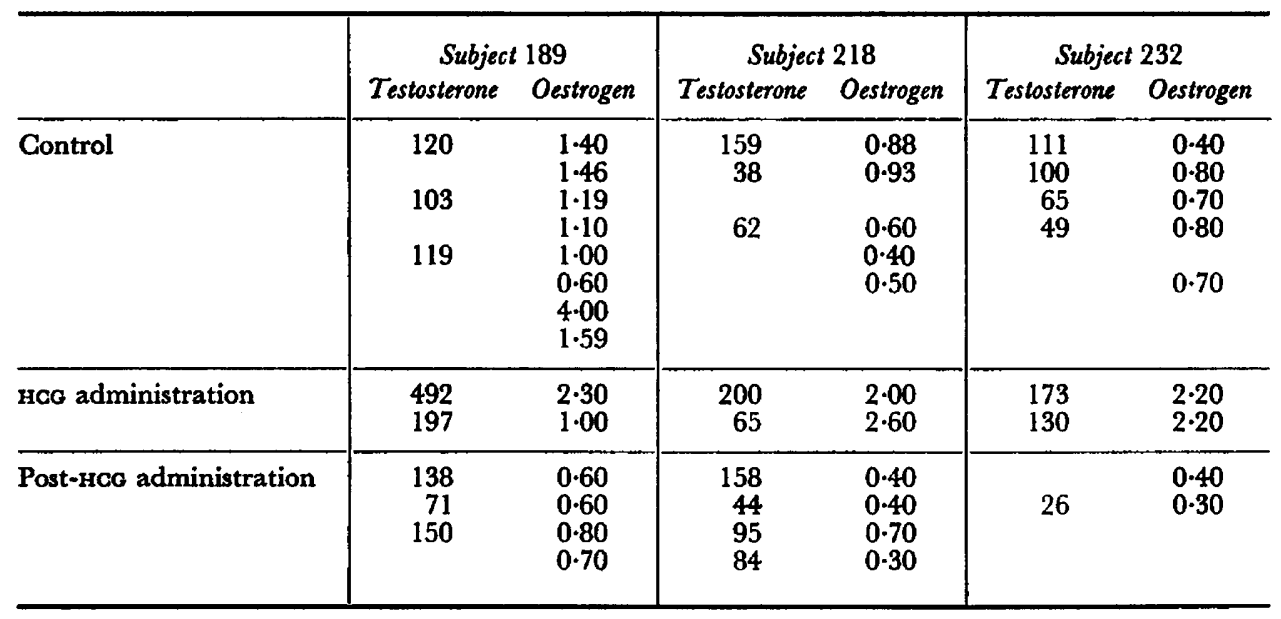

$* \mathrm{gg} / 24 \mathrm{hr}$.

$\dagger \mu \mathrm{g}$ oestradiol benzoate/24 hr.

TABLE 5

CONTROL, ADMINISTRATION AND POSTADMINISTRATION MONTHLY TESTOSTERONE* VALUES (16 WEEKS HCG ADMINISTRATION EVERY 2ND DAY)

\begin{tabular}{l|c|c|c}
\hline & Subject 44 & Subject 251 & Subject 253 \\
\hline Control & 85 & 94 & 49 \\
& 86 & 86 & 82 \\
& 76 & 58 & 50 \\
& & & 64 \\
& & & $77(2)$ \\
\hline HCG administration & $299(12)$ & $257(7)$ & $142(6)$ \\
& $246(8)$ & $192(5)$ & $61(4)$ \\
& $278(6)$ & $146(3)$ & $58(6)$ \\
& $412(4)$ & $140(2)$ & $93(2)$ \\
& & & 86 \\
\hline Post-HCG administration & 370 & $172(2)$ & $92(3)$ \\
& $158(2)$ & $210(2)$ & $117(3)$ \\
& $118(15)$ & & 53 \\
& $164(14)$ & & $55(2)$ \\
& & & 50 \\
\hline
\end{tabular}

Figures in parentheses indicate number of daily values for monthly mean.

* $\mu \mathrm{g} / 24 \mathrm{hr}$.

Effect of HCG on urinary oestrogen

Oestrogen levels rose significantly at an HCG dose of 4000 i.u. three times a week in two of three subjects and there was also some suggestion of a rise in Subject 189 (Table 4). 

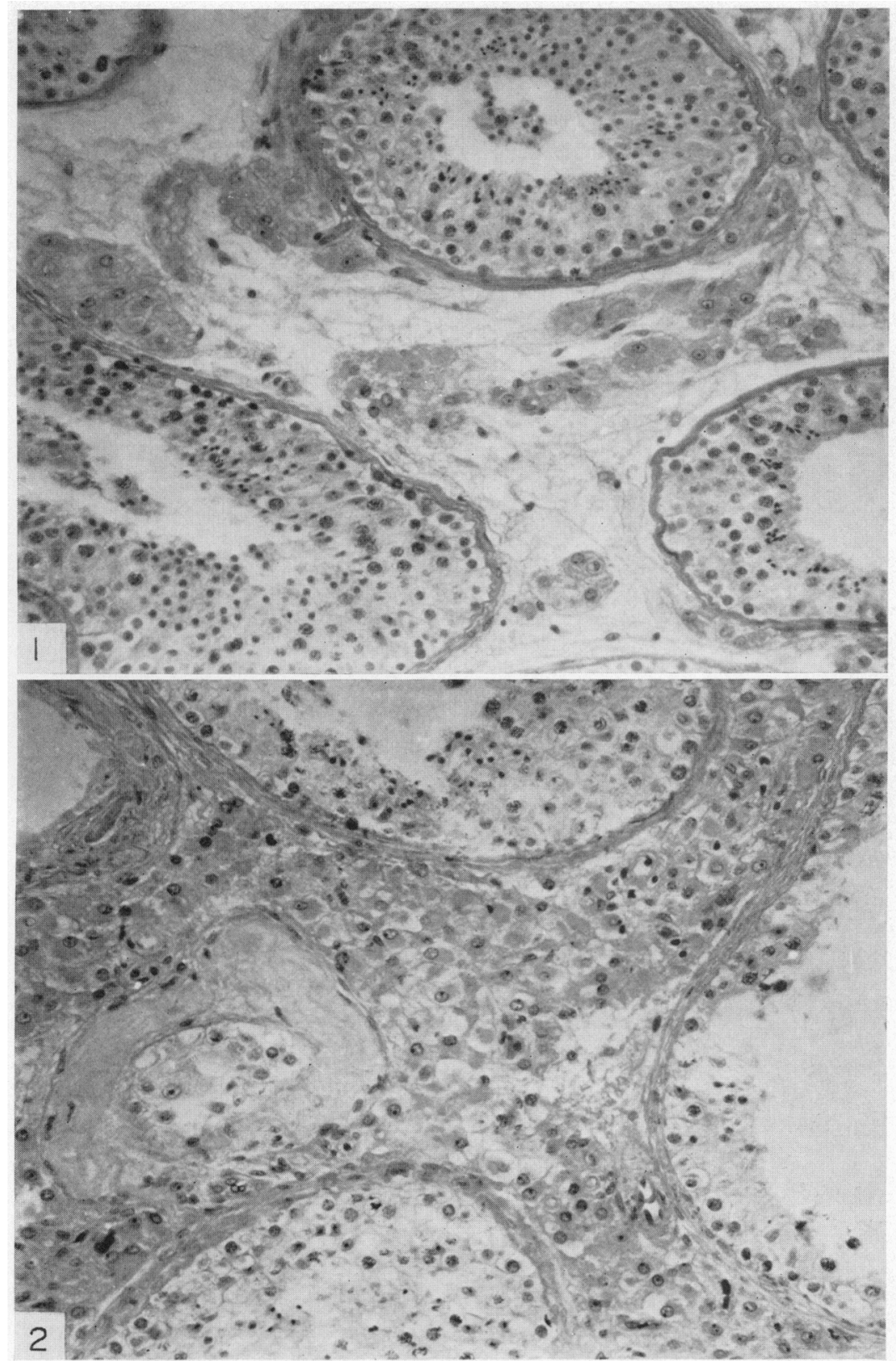

FIG. 1. Control biopsy of Subject 251. $\times 160$.

Fis. 2. Biopsy of Subject 251 following 16 weeks of administration of nac: Note denuding of germinal cells and subjective impression of an increase in Leydig-cell numbers. $\times 160$. 


\section{DISGUSSION}

The results of this experiment support previous data that HCG stimulates Leydig-cell activity (as exhibited by the increased testosterone and oestrogen production). To determine whether the increased function was correlated with an increase in Leydig-cell numbers and/or size, both were quantified. An increase in size but not in numbers was encountered. The failure to confirm the subjectively derived conclusions of Maddock \& Nelson (1952) may be explained as follows: administration of HCG to normal men not only acts to increase Leydig-cell function but also causes depletion of the germinal cells. During the denuding of germinal cells, shrinkage was observed in the diameter, but not in length of the tubules at 6 weeks and in both diameter and length by 16 weeks. The shrinkage in length was revealed by the increased Sertoli-cell concentration per tubular cross section. As the tubules, and, therefore, the testis shrink, the interstitial area becomes more compact. This condensation then gives the subjective impression that the elements of the interstitial area, including the Leydig cells, are increased in numbers. After 16 weeks of HCG administration, the biopsy of Subject 251 showed an apparently large increase in the number of Leydig cells as compared to his pretreatment control biopsy (cf. Pl. 1, Fig. 1 with Pl. 1, Fig. 2). The LC/SG ratio revealed no significant change in this subject's Leydig-cell numbers following HCG administration (Table 1). Since Leydig-cell numbers remained relatively constant during HCG administration, it is concluded that their increased activity is not related to their numbers. Measuring the individual Leydig cells revealed an increase in the size of the nucleus and cytoplasm. This increase in Leydig-cell size coupled with their being more condensed in interstitial area, might give the subjective impression that there was an increase in number. The increased activity of the Leydig cells following HGG administration may be related to an increase in their size.

That stimulation of normal human Leydig cells was not revealed by an increase in their number does not imply that this may not occur under other abnormal circumstances. Preliminary results in our laboratory reveal that Leydig-cell numbers may increase following X-ray irradiation exposure of normal human testes. This is associated with some diminution of testosterone output. One might speculate that radiation damage to the Leydig cells might evoke a compensatory mechanism, i.e. an increase in their number. The subjective increase in Leydig-cell numbers in instances of Klinefelter's syndrome associated with declining androgen production might (if quantified) reveal a similar compensatory increase in Leydig cells. However, neither in the presence of HCG administration nor of X-ray exposure have we observed mitotic divisions of Leydig cells. The increased number of mature Leydig cells is probably derived from undifferentiated forms already present in the interstitial tissue.

The increase in cell size, reflected in the increase of Leydig-cell and nuclear size, definitely relates increase in function with morphological alterations. Such alterations may well be reflected in other parameters as revealed by histochemical or ultrastructural observations.

This study emphasizes that Leydig cells are capable of increasing output above normal control function. This has its natural parallel in the thyroid and 
adrenal cortical glands as reflected by hyperthyroidism and hyperadrenocorticism but, except as an association with malignancies or other tumour-cell formation, no naturally occurring documented hyper-Leydigism is known.

\section{AGKNOWLEDGMENTS}

We wish to thank Florence Teshima for her excellent technical assistance in preparing the biopsy material, Dr Kathleen B. O'Keefe for her statistical evaluation of the data, and Mavis J. Rowley and Gary V. Heller for their critical assessment of the manuscript.

This investigation was supported by grants from the USPHS-HD 00804, The Population Council-M67.122 and the U.S. Atomic Energy CommissionAT(45-1) 1780 .

\section{REFERENCES}

Gleveland, W. W., Ahmad, N., Sandberg, D. H. \& Savard, K. (1966) Excretion of testosterone and 17-ketosteroids following administration of HCG and ACTH to normal adult males. Steroids, 8, 149.

Heller, C. G., Lalli, M. F., Pearson, J. E. \& Leach, D. R. (1971) A method for the quantification of Leydig cells in man. 7. Reprod. Fert. 25, 177.

Lauson, H. D., Heller, C. G., Golden, J. B. \& Sevringhaus, E. L. (1939) The immature rat uterus in the assay of estrogenic substances, and a comparison of estradiol, estrone and estriol. Endocrinology, 24, 35.

Leach, R. B., Maddock, W. D., Tokuyama, I., Paulsen, G. A. \& Nelson, W. O. (1956) Glinical studies of testicular hormone production. Recent Prog. Horm. Res. 12, 377.

Maddock, W. O., Epstein, M. \& Nelson, W. O. (1952) The assay of urinary estrogens as a test of human Leydig cell function. Ann. N.Y. Acad. Sci. 55, 657.

Maddock, W.O. \& NeLson, W.O. (1952) The effects of chorionic gonadotropin in adult men: increased estrogen and 17-ketosteroid excretion, gynecomastia, Leydig cell stimulation and seminiferous tubule damage. F. clin. Endocr. Metab. 12, 985.

RowLEX, M.J. \& HeLler, C. G. (1966) The testicular biopsy: surgical procedure, fixation and staining technics. Fert. Steril. 17, 177.

Tamm, J., Apostolakis, M. \& Vorght, K. D. (1965) The effect of HCG and ACTH administration on testosterone excretion in male subjects with various endocrinopathies. (Abstract). Acta endocr., Copenh. Suppl. 100, 49. 